\title{
Wild and commercial mushrooms as source of nutrients and nutraceuticals
}

\author{
Lillian Barros, Telma Cruz, Paula Baptista, Letícia M. Estevinho, Isabel C.F.R. Ferreira* \\ CIMO/Escola Superior Agrária, Instituto Politécnico de Bragança, Campus de Santa Apolónia, Apartado 1172, 5301-855 Bragança, Portugal
}

\section{A R T I C L E I N F O}

\section{Article history:}

Received 29 February 2008

Accepted 24 April 2008

\section{Keywords:}

Mushrooms

Wild and commercial sp.

Nutrients

Nutraceuticals

Antimicrobials

\begin{abstract}
A B S T R A C T
In order to promote the use of mushrooms as source of nutrients and nutraceuticals, several experiments were performed in wild and commercial species. The analysis of nutrients included determination of proteins, fats, ash, and carbohydrates, particularly sugars by HPLC-RI. The analysis of nutraceuticals included determination of fatty acids by GC-FID, and other phytochemicals such as tocopherols, by HPLC-fluorescence, and phenolics, flavonoids, carotenoids and ascorbic acid, by spectrophotometer techniques. The antimicrobial properties of the mushrooms were also screened against fungi, Gram positive and Gram negative bacteria. The wild mushroom species proved to be less energetic than the commercial sp., containing higher contents of protein and lower fat concentrations. In general, commercial species seem to have higher concentrations of sugars, while wild sp. contained lower values of MUFA but also higher contents of PUFA. $\alpha$-Tocopherol was detected in higher amounts in the wild species, while $\gamma$-tocopherol was not found in these species. Wild mushrooms revealed a higher content of phenols but a lower content of ascorbic acid, than commercial mushrooms. There were no differences between the antimicrobial properties of wild and commercial species. The ongoing research will lead to a new generation of foods, and will certainly promote their nutritional and medicinal use.
\end{abstract}

(c) 2008 Elsevier Ltd. All rights reserved.

\section{Introduction}

A nutraceutical can be defined as a substance that may be considered a food or part of a food and provides medical or health benefits like the prevention and treatment of disease. Nutraceuticals may range from isolated nutrients and dietary supplements to genetically engineered "designer" foods, herbal products and processed products such as cereals, soups and beverages. Some examples of nutritive nutraceuticals or "functional food ingredients" are dietary fiber, polyunsaturated fatty acids (PUFA, fish oil), proteins, peptides, amino acids, keto acids, minerals, antioxidative vitamins and other antioxidants (glutathione, selenium, etc) (Andlauer and Fürst, 2002; Kruger and Mann, 2003). PUFAs, especially the n-3 fatty acid family, are claimed to exert a protective effect against the development of cardiovascular and inflammatory diseases (Fürst and Kuhn, 2000; Fang et al., 2002). Epidemiological studies have consistently shown an inverse association between consumption of vegetables and fruits and the risk of cardiovascular diseases (Bazzano et al., 2001) and certain forms of cancer (Liu, 2003). Although the protective effects have been primarily attributed to well-known antioxidants, such as ascorbic acid, tocopherols and $\beta$-carotene, plant phenolics may also play a significant role (Soobrattee et al., 2005).

Different mushrooms were studied by the scientific community, in searching for new therapeutic alternatives, and the results

\footnotetext{
* Corresponding author. Tel.: +351 273 303219; fax: +351 273325405

E-mail address: iferreira@ipb.pt (I.C.F.R. Ferreira).
}

proved their bioactive properties (Lindequist et al., 2005). Mushrooms are rich sources of nutraceuticals (Çağlarirmak, 2007; Elmastas et al., 2007; Ribeiro et al., 2007) responsible for their antioxidant (Mau et al., 2002; Lo and Cheung, 2005; Barros et al., 2007a), antitumor (Wasser and Weis, 1999), and antimicrobial properties (Smânia et al., 1995; Hirasawa et al., 1999; Hatvani, 2001; Barros et al., 2007b; Turkoglu et al., 2007). Besides their pharmacological features (Lindequist et al., 2005), wild mushrooms are becoming more important in our diet due to their nutritional value, related to the high protein and low fat/energy contents (Diéz and Alvarez, 2001; Agahar-Murugkar and Subbulakshmi, 2005; Barros et al., 2007c).

Our research group has been interested in nutritional and bioactive properties of wild mushrooms such as antioxidant activity (Barros et al. 2007a), antimicrobial activity (Barros et al., 2007b), and the influence of conservation treatment/cooking (Barros et al., 2007d) and fruiting body maturity stage (Barros et al., 2007e) on these properties.

In the present study we intend to evaluate the composition of wild and commercial mushrooms in nutrients and nutraceuticals. The evaluation of nutrient composition included the determination of proteins, fats, ash, carbohydrates, and individual profile of sugars. The evaluation of nutraceutical composition included the determination of fatty acids, phenolics, flavonoids, carotenoids, ascorbic acid and tocopherols. Antimicrobial activity was screened against fungi, Gram positive and Gram negative bacteria, and correlated to the bioactive compounds present in the extracts. 


\section{Materials and methods}

\subsection{Samples}

Eight mushrooms species: Boletus edulis Fr., Calocybe gambosa (Fr.) Donk, Cantharellus cibarius L. ex Fr., Craterellus cornucopioides Pers., Marasmius oreades (Bolt. ex Fr.) Fr. were commercial dried samples obtained in several supermarkets. All the others (Agaricus bisporus (Lange) Imbach, Agaricus silvaticus Schaeff., Agaricus silvicola (Vittad.) Peck were wild species and were collected under grassland in Bragança (Northeast of Portugal), in autumn 2006. The morphological identification of the wild macrofungi was made till species according to macro and microscopic characteristics, and following several authors (Moser, 1983; Courtecuisse and Duhem, 1995) and representative voucher specimens were deposited at the herbarium of Escola Superior Agrária of Instituto Politécnico de Bragança. After collection and taxonomic identification, those mushrooms were lyophilized (Ly-8-FM-ULE, Snijders, HOLLAND) before analysis.

\subsection{Standards and reagents}

Acetonitrile $99.9 \%, n$-hexane $95 \%$ and ethyl acetate $99.8 \%$ were of HPLC grade from Lab-Scan (Lisbon, Portugal). All the other reagents were of analytical grade purity: methanol and diethyl ether were supplied by Lab-Scan (Lisbon, Portugal); toluene from Riedel-de-Haën; sulphuric acid from Fluka (St. Gallen, Switzerland) The fatty acids methyl ester (FAME) reference standard mixture 37 (fatty acids C4-C24; (standard 47885-U) was from Supelco (Bellefonte, PA, USA) and purchased from Sigma (St. Louis, MO, USA), as also other individual fatty acid isomers, tocopherol standards $(\alpha, \beta, \gamma$ and $\delta)$, and the standards gallic acid and (+)-catechin. The standards used in the antimicrobial activity assays, ampicillin and cycloheximide, as also butylated hydroxytoluene (BHT) were purchased from Merck (Darmstadt, Germany). All other chemicals were obtained from Sigma Chemical Co. (St. Louis, MO, USA). Water was treated in a Mili-Q water purification system (TGI Pure Water Systems, USA).

\subsection{Nutrient composition}

\subsubsection{Nutritional value}

Samples of mushrooms were analysed for chemical composition (protein, fat, carbohydrates and ash) using the AOAC procedures (1995). The crude protein content $(N \times 4.38)$ of the samples was estimated by the macroKjeldahl method; the crude fat was determined by extracting a known weight of powdered mushroom sample with petroleum ether, using a Soxhlet apparatus; the ash content was determined by incineration at $600 \pm 15^{\circ} \mathrm{C}$; reducing sugars were determined by DNS (dinitrosalicylic acid) method. Total carbohydrates were calculated by difference: Total carbohydrates $=100-(\mathrm{g}$ moisture $+\mathrm{g}$ protein $+\mathrm{g}$ fat $+\mathrm{g}$ ash $)$. Total energy was calculated according to the following equations: Energy $(\mathrm{kJ})=17 \times(\mathrm{g}$ protein $+\mathrm{g}$ carbohydrate $)+37 \times(\mathrm{g}$ lipid $)$.

\subsubsection{Sugar composition}

Free sugars were determined by high performance liquid chromatography coupled to a refraction index detector (HPLC-RI) based on the method used by Harada et al. (2004) with minor modifications. Dried powder $(1.0 \mathrm{~g})$ was extracted with $40 \mathrm{ml}$ of $80 \%$ aqueous ethanol at $80^{\circ} \mathrm{C}$ for $30 \mathrm{~min}$. The resulting suspension was centrifuged at $15,000 \mathrm{~g}$ for $10 \mathrm{~min}$. The supernatant was concentrated at $60^{\circ} \mathrm{C}$ under reduced pressure and defatted three times with $10 \mathrm{ml}$ of ethyl ether, successively. After concentration at $40{ }^{\circ} \mathrm{C}$, the solid residues were dissolved in water to a final volume of $5 \mathrm{ml}$. Soluble sugars were determined by using HPLC (Knauer, Smartline system) at $35^{\circ} \mathrm{C}$. The HPLC system was equipped with a Knauer Smartline $2300 \mathrm{R}$ detector and with a Eurospher 100-5 $\mathrm{NH}_{2}$ column $(4.6 \times 250 \mathrm{~mm}, 5 \mathrm{~mm}$, Knauer). The mobile phase was acetonitrile/deionized water, $7: 3(\mathrm{v} / \mathrm{v})$ at a flow rate of $1.25 \mathrm{ml} / \mathrm{min}$. The results are expressed in $\mathrm{g} / 100 \mathrm{~g}$ of dry weight, calculated by internal normalization of the chromatographic peak area. Sugar identification was made by comparing the relative retention times of sample peaks with standards. The sugar standards used for identification were purchased from Sigma Chemical Co. (St. Louis, USA): $\mathrm{L}(+)$-arabinose, $\mathrm{D}(-)$-fructose, $\mathrm{D}(+)$-galactose, $\mathrm{D}(+)$-glucose anhydrous, lactose 1 -hydrate, maltose 1 -hydrate, $\mathrm{D}(+)$-mannitol, $\mathrm{D}(+)$-mannose, $\mathrm{D}(+)$-melezitose, $\mathrm{D}(+)$-melibiose monohydrate, $\mathrm{L}(+)$-rhamnose monohydrate, $\mathrm{D}(+)$-sucrose, $\mathrm{D}(+)$-trehalose and $\mathrm{D}(+)$-xylose.

\subsection{Nutraceutical composition}

\subsubsection{Fatty acid composition}

Fatty acids were determined by gas-liquid chromatography with flame ionization detection (GLC-FID)/capillary column based on the following trans-esterification procedure: fatty acids were methylated with $5 \mathrm{~mL}$ of methanol:sulphuric acid:toluene 2:1:1 (v:v), during at least $12 \mathrm{~h}$ in a bath at $50^{\circ} \mathrm{C}$ and $160 \mathrm{rpm}$; then $5 \mathrm{~mL}$ of deionised water were added, to obtain phase separation; the FAME were recovered with $5 \mathrm{~mL}$ of diethyl ether by shaking in vortex, and the upper phase was passed through a micro-column of sodium sulphate anhydrous, in order to eliminate the water; the sample was recovered in a vial with Teflon, and before injection the sample was filtered with $0.2 \mu \mathrm{m}$ nylon filter from Milipore. The fatty acid profile was analyzed with a DANI model GC 1000 instrument equipped with a split/splitless injector, a flame ionization detector (FID) and a Macherey-Nagel column $\left(30 \mathrm{~m} \times 0.32 \mathrm{~mm}\right.$ ID $\left.\times 0.25 \mu \mathrm{m} d_{f}\right)$. The oven temperature program was as follows: the initial temperature of the column was $50^{\circ} \mathrm{C}$, held for $2 \mathrm{~min}$, then a $10^{\circ} \mathrm{C} /$ min ramp to $240^{\circ} \mathrm{C}$ and held for $11 \mathrm{~min}$. The carrier gas (hydrogen) flow-rate was $4.0 \mathrm{~mL} / \mathrm{min}(0.61 \mathrm{bar})$, measured at $50{ }^{\circ} \mathrm{C}$. Split injection $(1: 40)$ was carried out at $250{ }^{\circ} \mathrm{C}$. For each analysis $1 \mu \mathrm{L}$ of the sample was injected in GC. Fatty acid identification was made by comparing the relative retention times from samples with FAME peaks (standards). The results were recorded and processed using CSW 1.7 software (DataApex 1.7) and expressed in relative percentage of each fatty acid.

\subsubsection{Tocopherol composition}

BHT solution in hexane $(10 \mathrm{mg} / \mathrm{mL} ; 100 \mu \mathrm{L})$ and IS solution in hexane ( $\delta$ tocopherol; $1.6 \mu \mathrm{g} / \mathrm{mL} ; 250 \mu \mathrm{L}$ ) were added to the sample prior to the extraction procedure. The samples $(\sim 500 \mathrm{mg})$ were homogenized with methanol $(4 \mathrm{~mL})$ by vortex mixing $(1 \mathrm{~min})$. Subsequently, hexane $(4 \mathrm{~mL})$ was added and again vortex mixed for $1 \mathrm{~min}$. After that, saturated $\mathrm{NaCl}$ aqueous solution $(2 \mathrm{~mL})$ was added, the mixture was homogenized ( $1 \mathrm{~min}$ ), centrifuged ( $5 \mathrm{~min}, 4000 \mathrm{~g}$ ) and the clear upper layer was carefully transferred to a vial. The sample was re-extracted twice with hexane. The combined extracts were taken to dryness under a nitrogen stream, redissolved in $1 \mathrm{~mL}$ of $n$-hexane, dehydrated with anhydrous sodium sulphate, filtered through a $0.22 \mu \mathrm{m}$ disposable LC filter disk, transferred into a dark injection vial and analysed by HPLC. The HPLC equipment consisted of an integrated system with a Smartline pump 1000 (Knauer, Germany), a degasser system Smartline manager 5000, an AS-2057 auto-sampler and a 2500 UV detector at $295 \mathrm{~nm}$ (Knauer, Germany) connected in series with a FP-2020 fluorescence detector (Jasco, Japan) programmed for excitation at $290 \mathrm{~nm}$ and emission at $330 \mathrm{~nm}$. Data were analysed using Clarity 2.4 Software (DataApex). The chromatographic separation was achieved with a Polyamide II $(250 \times 4.6 \mathrm{~mm})$ normal-phase column from YMC Waters (Japan) operating at $30{ }^{\circ} \mathrm{C}$ (7971 R Grace oven). The mobile phase used was a mixture of $n$-hexane and ethyl acetate $(70: 30, v / v)$ at a flow rate of $1 \mathrm{~mL} / \mathrm{min}$, and the injection volume was $20 \mu \mathrm{L}$. The compounds were identified by chromatographic comparisons with authentic standards. Quantification was based on the fluorescence signal response, using the internal standard method. Tocopherol contents in mushroom samples are expressed in $\mu \mathrm{g}$ per $\mathrm{g}$ of dry mushroom.

\subsubsection{Total bioactive compounds}

Bioactive compounds were determined after methanolic extraction of the samples. Phenols, flavonoids, ascorbic acid and carotenoids were determined according to procedures previously described by us (Barros et al., 2007e). For phenolic compound determination in the mushroom extracts, $1 \mathrm{~mL}$ of sample was mixed with $1 \mathrm{~mL}$ of Folin and Ciocalteu's phenol reagent. After $3 \mathrm{~min}, 1 \mathrm{~mL}$ of saturated sodium carbonate solution was added to the mixture and adjusted to $10 \mathrm{~mL}$ with distilled water. The reaction was kept in the dark for $90 \mathrm{~min}$, after which the absorbance was read at $725 \mathrm{~nm}$ (Analytikijena 200-2004 spectrophotometer). Gallic acid was used to calculate the standard curve $(0.01-0.4 \mathrm{mM} ; Y=2.8557 \mathrm{X}-0.0021$; $R^{2}=0.9999$ ) and the results were expressed as mg of gallic acid equivalents (GAEs) per $g$ of extract.

For flavonoid contents determination the mushroom extract $(250 \mu \mathrm{L})$ was mixed with $1.25 \mathrm{~mL}$ of distilled water and $75 \mu \mathrm{L}$ of a $5 \% \mathrm{NaNO}_{2}$ solution. After $5 \mathrm{~min}, 150 \mu \mathrm{L}$ of a $10 \% \mathrm{AlCl}_{3} \cdot \mathrm{H}_{2} \mathrm{O}$ solution was added. After $6 \mathrm{~min}, 500 \mu \mathrm{L}$ of $1 \mathrm{M}$ $\mathrm{NaOH}$ and $275 \mu \mathrm{L}$ of distilled water were added to the mixture. The solution was mixed well and the intensity of pink colour was measured at $510 \mathrm{~nm}$. (+)-catechin was used to calculate the standard curve $(0.022-0.34 \mathrm{mM} ; Y=0.9629 \mathrm{X}-0.0002$; $\left.R^{2}=0.9999\right)$ and the results were expressed as $\mathrm{mg}$ of $(+)$-chatequin equivalents (CEs) per $g$ of extract.

For ascorbic acid determination the dried methanolic extract $(100 \mathrm{mg})$ was extracted with $10 \mathrm{~mL}$ of $1 \%$ metaphosphoric acid for $45 \mathrm{~min}$ at room temperature and filtered through Whatman No. 4 filter paper. The filtrate $(1 \mathrm{~mL})$ was mixed with $9 \mathrm{~mL}$ of 2,6-dichlorophenolindophenol and the absorbance was measured within $30 \mathrm{~min}$ at $515 \mathrm{~nm}$ against a blank. Content of ascorbic acid was calculated on the basis of the calibration curve of authentic L-ascorbic acid $(0.020-0.12 \mathrm{mg} / \mathrm{mL}$; $\left.Y=3.4127 \mathrm{X}-0.0072 ; R^{2}=0.9905\right)$ and the results were expressed as mg of ascorbic $\mathrm{acid} / \mathrm{g}$ of extract.

For $\beta$-carotene and lycopene determination the dried methanolic extract $(100 \mathrm{mg})$ was vigorously shaken with $10 \mathrm{~mL}$ of acetone-hexane mixture (4:6) for $1 \mathrm{~min}$ and filtered through Whatman No. 4 filter paper. The absorbance of the filtrate was measured at 453, 505 and $663 \mathrm{~nm}$. Contents of -carotene and lycopene were calculated according to the following equations: lycopene $(\mathrm{mg} /$ $100 \mathrm{~mL})=-0.0458 \times \mathrm{A} 663+0.372 \times \mathrm{A} 505-0.0806 \times \mathrm{A} 453 ; \beta$-carotene $(\mathrm{mg} /$ $100 \mathrm{~mL})=0.216 \times \mathrm{A} 663-0.304 \times \mathrm{A} 505+0.452 \times \mathrm{A} 453$. The results were expressed as $\mu \mathrm{g}$ of carotenoid/g of extract. 


\subsection{Antimicrobial activity}

The assays were performed in the methanolic extracts after redissolution in DMSO at a concentration of $50 \mathrm{mg} / \mathrm{mL}$.

\subsubsection{Microorganisms and culture conditions}

Microorganisms labeled CECT were obtained from the Spanish type culture collection (CECT) of Valencia University, while microorganisms labeled ESA were clinically isolated strains from different biological fluids, identified by Microbiology Laboratory of Escola Superior Agrária de Bragança. Gram + (Bacillus cereus CECT 148, B. subtilis CECT 498, Staphylococus aureus ESA 7 isolated from pus) and Gram - (Escherichia coli CECT 101, Pseudomonas aeruginosa CECT 108, Klebsiella pneumoniae ESA 8 isolated from urine) bacteria, and fungi (Candida albicans CECT 1394, Cryptococcus neoformans ESA 3 isolated from vaginal fluid) were used to screen samples antimicrobial activity. Microorganisms were cultured aerobically at $37{ }^{\circ} \mathrm{C}$ (Scientific 222 oven model, 2003) in nutrient agar medium for bacteria, and at $30{ }^{\circ} \mathrm{C}$ (Scientific 222 oven model, 2003) in sabouraud dextrose agar medium for fungi.

\subsubsection{Test assays for antimicrobial activity}

A screening of antibacterial activities against the Gram - and Gram + bacteria and fungi was performed, and the minimal inhibitory concentration (MIC) was determined by an adaptation of the agar streak dilution method based on radial diffusion (Barros et al., 2007b). Suspensions of the microorganisms were prepared to contain approximately $10^{8} \mathrm{cfu} / \mathrm{mL}$, and the plates containing agar medium were inoculated $(100 \mu \mathrm{L})$. A $50 \mu \mathrm{L}$ volume of each sample was placed in a hole (depth $3 \mathrm{~mm}$, diameter $4 \mathrm{~mm}$ ) made in the centre of the agar. Under the same conditions, different DMSO solutions of ampicillin (antibacterial) and cycloheximide (antifungal) were used as standards. DMSO was chosen as the best solvent after comparative toxicity assays which proved its non toxicity. The MIC was considered to be the lowest concentration of the tested sample able to inhibit the growth of bacteria or fungi, after $24 \mathrm{~h}$. The inhibition halos corresponding to the MICs were measured using a ruler, with an accuracy of $0.5 \mathrm{~mm}$. Each inhibition halo was measured three times (three different plates) and the average was considered. A control using only inoculation was also carried out.

\subsection{Statistical analysis}

For each one of the mushroom species three samples were analysed and also all the assays were carried out in triplicate. The results are expressed as mean values and standard deviation (SD). The results were analyzed using one-way analysis of variance (ANOVA) followed by Tukey's HSD Test with $\alpha=0.05$, using SAS v. 9.1.3 program.

\section{Results}

\subsection{Nutrient composition}

The results of the chemical composition and estimated energetic value (expressed on dry weight basis) of the wild and commercial edible mushrooms are shown in Table 1 . Protein was found in high levels and varied between $17.18 \mathrm{~g} / 100 \mathrm{~g}$ in B. edulis and $80.93 \mathrm{~g} / 100 \mathrm{~g}$ in $A$. bisporus. Fat ranged from $0.92 \mathrm{~g} / 100 \mathrm{~g}$ in A. bisporus and $4.88 \mathrm{~g} / 100 \mathrm{~g}$ in C. cornucopioides. In general, wild mushrooms were richer sources of protein and had a lower amount of fat than commercial mushrooms. Carbohydrates, calculated by difference, were also an abundant macronutrient and ranged from $8.25 \mathrm{~g} / 100 \mathrm{~g}$ in A. bisporus and $71.15 \mathrm{~g} / 100 \mathrm{~g}$ in B. edulis. Reducing sugars are only a small part of carbohydrates content, being polysaccharides such as chitin and starch the most abundant carbohydrates in mushrooms. Ash content varied between $7.07 \mathrm{~g} / 100 \mathrm{~g}$ in B. edulis and $16.48 \mathrm{~g} / 100 \mathrm{~g}$ in A. silvaticus. Wild mushroom species proved to be less energetic providing, on average, $1502 \mathrm{~kJ}$ per $100 \mathrm{~g}$ of a dry portion, when compared to the $1597 \mathrm{~kJ}$ assured by the commercial sp. The highest energetic value was obtained for the commercial $B$. edulis, while the wild A. silvaticus gave the lowest energetic contribution (Table 1).

The edible mushrooms contained mannitol and trehalose as the principal carbohydrates (Table 2). The accumulation of these sugars in the fruit-bodies of other species was already reported (Harada et al., 2004; Barros et al., 2007c). Nevertheless, the present study also describes the presence of maltose (disaccharide) and melezitose (non-reducing trisaccharide) in some of the studied species. A. bisporus revealed the highest sugar contents $(20.87 \mathrm{~g} / 100 \mathrm{~g})$, while A. silvaticus revealed the lowest levels ( $3.72 \mathrm{~g} / 100 \mathrm{~g})$.With the exception of $A$. bisporus, the commercial species seem to have higher concentration of sugars. Otherwise, maltose was not found in none of the commercial mushrooms. This sugar can be broken down into two glucose molecules by hydrolysis, and the drying process to which commercial sp. were submitted could be responsible for the degradation of maltose. Melezitose is obtained especially from exudations of various trees or from honey made from such exudations, and therefore incorporated by some mushrooms.

\subsection{Nutraceutical composition}

The results of fatty acid composition, total saturated fatty acids (SFA), monounsaturated fatty acids (MUFA), and polyunsaturated fatty acids (PUFA) of the studied mushrooms are shown in Table 3. In general, the major fatty acid found in the studied species was linoleic acid (C18:2), followed by oleic acid (C18:1) and palmitic acid (C16:0). Besides the three main fatty acids already described, eighteen more were identified and quantified. PUFA were the main group of fatty acids in all species with the exception of $C$. cornucopiodes, where MUFA were the main group. Wild Agaricus sp. contained a lower value of MUFA but also a higher content of PUFA than the commercial species, due to the higher contribution of linoleic acid. The commercial C. gambosa revealed the highest SFA values, due to the contribution of palmitic acid. Nevertheless, UFA predominated over SFA in all the studied mushrooms, ranging from $77 \%$ to $85 \%$. The commercial $B$. edulis contained the highest UFA (85\%) and the lowest SFA levels (15\%).

Tocopherol contents in the eight studied mushroom, including three wild (Barros et al., 2008) and five commercial species is presented in Table 4. $\alpha$ and $\beta$-Tocopherol were found in all species. The first isomer was found in higher amounts in the wild species, while significant differences were not observed in $\beta$-tocopherol content of wild and commercial sp. $\gamma$-Tocopherol was only found in the commercial species.

Table 1

Proximate chemical composition $(\mathrm{g} / 100 \mathrm{~g})$ and energetic value $(\mathrm{kJ} / 100 \mathrm{~g})$ of wild and commercial mushrooms (mean $\pm \mathrm{SD} ; n=3$ )

\begin{tabular}{|c|c|c|c|c|c|c|}
\hline Specie & Total fat & Crude protein & Ash & Carbohydrates & Reducing sugars & Energy \\
\hline Agaricus bisporus & $0.92 \pm 0.06 \mathrm{~d}$ & $80.93 \pm 3.53 \mathrm{a}$ & $9.90 \pm 0.05 \mathrm{~d}$ & $8.25 \pm 1.42 \mathrm{~d}$ & $1.44 \pm 0.02 \mathrm{cb}$ & $1550.05 \pm 21.65 c$ \\
\hline Agaricus silvaticus & $2.05 \pm 0.01 c$ & $71.99 \pm 4.59 \mathrm{~b}$ & $16.48 \pm 0.23 \mathrm{a}$ & $9.49 \pm 2.84 \mathrm{~d}$ & $2.36 \pm 0.15 \mathrm{cb}$ & $1460.87 \pm 23.88 \mathrm{e}$ \\
\hline Agaricus silvicola & $2.43 \pm 0.22 \mathrm{cb}$ & $70.47 \pm 2.01 \mathrm{~b}$ & $14.93 \pm 0.66 \mathrm{~b}$ & $12.18 \pm 2.02 \mathrm{~d}$ & $2.00 \pm 0.08$ ed & $1494.82 \pm 13.89 \mathrm{~d}$ \\
\hline Boletus edulis & $4.60 \pm 0.13 a$ & $17.18 \pm 0.92 \mathrm{e}$ & $7.07 \pm 0.59 \mathrm{e}$ & $71.15 \pm 1.55 \mathrm{a}$ & $3.39 \pm 0.30 \mathrm{a}$ & $1671.83 \pm 18.72 \mathrm{a}$ \\
\hline Calocybe gambosa & $1.05 \pm 0.10 \mathrm{~d}$ & $47.22 \pm 1.32 \mathrm{~d}$ & $8.72 \pm 0.81 d$ & $43.01 \pm 1.31 \mathrm{~b}$ & $1.26 \pm 0.06$ ed & $1566.23 \pm 11.07 \mathrm{~b}$ \\
\hline Cantharellus cibarius & $4.49 \pm 0.06 \mathrm{a}$ & $69.14 \pm 3.26 b$ & $12.12 \pm 0.26 \mathrm{c}$ & $14.25 \pm 3.96 \mathrm{~d}$ & $2.54 \pm 0.16 \mathrm{cb}$ & $1572.87 \pm 22.63 \mathrm{cb}$ \\
\hline Craterellus cornucopioides & $4.88 \pm 020 \mathrm{a}$ & $69.45 \pm 1.24 \mathrm{~b}$ & $12.22 \pm 0.81 \mathrm{c}$ & $13.44 \pm 1.85 \mathrm{~d}$ & $2.70 \pm 0.29 \mathrm{~b}$ & $1583.78 \pm 14.28 \mathrm{~b}$ \\
\hline Marasmius oreades & $2.99 \pm 0.82 b$ & $52.22 \pm 2.57 \mathrm{c}$ & $11.39 \pm 0.09 c$ & $29.41 \pm 3.32 c$ & $2.21 \pm 0.33 \mathrm{cb}$ & $1589.91 \pm 12.07 \mathrm{cb}$ \\
\hline
\end{tabular}

Results are expressed in a dry weight basis. In each column different letters mean significant differences $(p<0.05)$. 
Table 2

Sugar composition $(\mathrm{g} / 100 \mathrm{~g})$ of wild and commercial mushrooms (mean $\pm \mathrm{SD} ; n=3$ )

\begin{tabular}{|c|c|c|c|c|c|}
\hline & Mannitol & Trehalose & Maltose & Melezitose & Total sugars \\
\hline Agaricus bisporus & $19.57 \pm 0.07 \mathrm{a}$ & $0.77 \pm 0.01 \mathrm{e}$ & nd & $0.53 \pm 0.00 \mathrm{~b}$ & $20.87 \pm 0.07 a$ \\
\hline Agaricus silvaticus & $2.65 \pm 0.02 \mathrm{f}$ & $0.25 \pm 0.15 \mathrm{fg}$ & $0.44 \pm 0.02 b$ & $0.38 \pm 0.05 \mathrm{cb}$ & $3.72 \pm 0.10 \mathrm{~g}$ \\
\hline Agaricus silvicola & $6.09 \pm 0.44 \mathrm{~d}$ & $0.66 \pm 0.07 \mathrm{fe}$ & $0.57 \pm 0.03 a$ & $0.47 \pm 0.01 \mathrm{cb}$ & $7.79 \pm 0.54 \mathrm{f}$ \\
\hline Boletus edulis & $3.46 \pm 0.19 \mathrm{e}$ & $9.71 \pm 0.19 b$ & nd & $0.29 \pm 0.01 \mathrm{~d}$ & $13.46 \pm 0.37 c$ \\
\hline Calocybe gambosa & $0.27 \pm 0.00 \mathrm{~g}$ & $8.01 \pm 0.38 c$ & nd & $0.85 \pm 0.11 \mathrm{a}$ & $9.13 \pm 0.48 \mathrm{e}$ \\
\hline Cantharellus cibarius & $8.33 \pm 0.09 c$ & $6.12 \pm 0.10 \mathrm{~d}$ & nd & nd & $14.45 \pm 0.19 b$ \\
\hline Craterellus cornucopioides & $10.67 \pm 0.20 b$ & $0.11 \pm 0.01 \mathrm{~g}$ & nd & nd & $10.78 \pm 0.21 \mathrm{~d}$ \\
\hline Marasmius oreades & $2.42 \pm 0.09 \mathrm{f}$ & $10.49 \pm 0.02 a$ & nd & $0.55 \pm 0.04 \mathrm{~b}$ & $13.46 \pm 0.03 c$ \\
\hline
\end{tabular}

Results are expressed in a dry weight basis. In each column different letters mean significant differences $(p<0.05)$.

nd - not detected.

Table 3

Fatty acid composition (percent) of wild and commercial mushrooms (mean \pm SD; $n=3$ )

\begin{tabular}{|c|c|c|c|c|c|c|c|c|}
\hline & A. bisporus & A. silvaticus & A. silvicola & B. edulis & C. gambosa & C. cibarius & C. cornucopioides & M. oreades \\
\hline C6:0 & $0.03 \pm 0.00$ & $0.03 \pm 0.00$ & $0.06 \pm 0.01$ & $0.02 \pm 0.00$ & $0.40 \pm 0.07$ & $0.67 \pm 0.05$ & $0.04 \pm 0.00$ & $0.19 \pm 0.02$ \\
\hline C8:0 & $0.03 \pm 0.00$ & $0.06 \pm 0.00$ & $0.06 \pm 0.00$ & $0.08 \pm 0.00$ & $0.12 \pm 0.03$ & $0.04 \pm 0.00$ & $0.13 \pm 0.01$ & $0.05 \pm 0.01$ \\
\hline C10:0 & $0.05 \pm 0.00$ & $0.07 \pm 0.00$ & $0.06 \pm 0.00$ & $0.01 \pm 0.00$ & $0.44 \pm 0.04$ & $0.01 \pm 0.00$ & $0.07 \pm 0.00$ & $0.02 \pm 0.00$ \\
\hline C12:0 & $0.05 \pm 0.01$ & $0.03 \pm 0.00$ & $0.03 \pm 0.00$ & $0.03 \pm 0.00$ & $0.19 \pm 0.01$ & $0.03 \pm 0.00$ & $0.07 \pm 0.01$ & $0.07 \pm 0.00$ \\
\hline C14:0 & $0.49 \pm 0.02$ & $0.32 \pm 0.01$ & $0.30 \pm 0.02$ & $0.15 \pm 0.00$ & $0.40 \pm 0.03$ & $0.13 \pm 0.00$ & $0.07 \pm 0.01$ & $0.15 \pm 0.04$ \\
\hline C15:0 & $1.03 \pm 0.02$ & $0.65 \pm 0.01$ & $0.85 \pm 0.07$ & $0.21 \pm 0.00$ & $0.65 \pm 0.06$ & $0.31 \pm 0.02$ & $0.22 \pm 0.00$ & $0.60 \pm 0.03$ \\
\hline C16:0 & $9.97 \pm 0.03$ & $11.74 \pm 0.08$ & $9.96 \pm 0.20$ & $10.03 \pm 0.28$ & $15.16 \pm 1.34$ & $13.08 \pm 0.14$ & $6.66 \pm 0.29$ & $13.82 \pm 0.26$ \\
\hline C16:1 & $0.14 \pm 0.02$ & $0.76 \pm 0.01$ & $0.58 \pm 0.04$ & $0.53 \pm 0.00$ & $0.88 \pm 0.08$ & $0.49 \pm 0.03$ & $0.18 \pm 0.01$ & $1.00 \pm 0.09$ \\
\hline C17:0 & $0.68 \pm 0.01$ & $0.39 \pm 0.00$ & $0.92 \pm 0.01$ & $0.15 \pm 0.00$ & $0.20 \pm 0.02$ & $0.19 \pm 0.01$ & $0.13 \pm 0.00$ & $0.07 \pm 0.02$ \\
\hline C18:0 & $4.08 \pm 0.10$ & $1.41 \pm 0.00$ & $2.64 \pm 0.20$ & $2.75 \pm 0.06$ & $2.14 \pm 0.27$ & $6.49 \pm 0.11$ & $7.83 \pm 0.40$ & $1.65 \pm 0.22$ \\
\hline C18:1n9c & $1.30 \pm 0.05$ & $6.67 \pm 0.01$ & $3.49 \pm 0.20$ & $39.72 \pm 1.64$ & $18.10 \pm 0.68$ & $10.78 \pm 0.34$ & $51.85 \pm 0.45$ & $28.52 \pm 1.72$ \\
\hline $\mathrm{C} 18: 2 \mathrm{n} 6 \mathrm{c}$ & $75.72 \pm 0.15$ & $74.78 \pm 0.01$ & $76.50 \pm 0.21$ & $44.32 \pm 2.02$ & $57.75 \pm 0.98$ & $53.59 \pm 0.12$ & $23.67 \pm 1.37$ & $50.66 \pm 0.63$ \\
\hline C18:3n3 & $0.06 \pm 0.00$ & $0.10 \pm 0.00$ & $0.05 \pm 0.00$ & $0.07 \pm 0.01$ & $0.45 \pm 0.07$ & $0.08 \pm 0.01$ & $0.07 \pm 0.01$ & $0.07 \pm 0.01$ \\
\hline C20:0 & $2.13 \pm 0.01$ & $0.85 \pm 0.01$ & $1.77 \pm 0.00$ & $0.44 \pm 0.02$ & $0.33 \pm 0.02$ & $0.31 \pm 0.02$ & $0.32 \pm 0.02$ & $0.30 \pm 0.03$ \\
\hline C20:1c & $0.07 \pm 0.01$ & $0.13 \pm 0.00$ & $0.12 \pm 0.00$ & $0.49 \pm 0.03$ & nd & $11.48 \pm 0.02$ & $7.57 \pm 0.05$ & nd \\
\hline$C 20: 2 c$ & $0.21 \pm 0.01$ & $0.15 \pm 0.00$ & nd & $0.14 \pm 0.00$ & $0.12 \pm 0.01$ & $0.17 \pm 0.00$ & $0.05 \pm 0.01$ & $0.20 \pm 0.01$ \\
\hline$C 20: 3 n 3+C 21: 0$ & $0.42 \pm 0.03$ & $0.21 \pm 0.03$ & $0.36 \pm 0.00$ & $0.03 \pm 0.00$ & $0.12 \pm 0.03$ & $0.23 \pm 0.02$ & nd & $0.03 \pm 0.00$ \\
\hline C22:0 & $1.62 \pm 0.00$ & $0.81 \pm 0.03$ & $1.30 \pm 0.18$ & $0.30 \pm 0.01$ & $0.59 \pm 0.05$ & $0.38 \pm 0.03$ & $0.35 \pm 0.05$ & $0.59 \pm 0.05$ \\
\hline C23:0 & $0.37 \pm 0.01$ & $0.21 \pm 0.03$ & $0.15 \pm 0.01$ & $0.04 \pm 0.00$ & $0.87 \pm 0.06$ & $0.11 \pm 0.01$ & $0.05 \pm 0.00$ & $0.22 \pm 0.02$ \\
\hline $\mathrm{C} 24: 0$ & $1.56 \pm 0.02$ & $0.55 \pm 0.03$ & $0.69 \pm 0.01$ & $0.31 \pm 0.00$ & $0.99 \pm 0.03$ & $0.88 \pm 0.06$ & $0.43 \pm 0.02$ & $1.16 \pm 0.08$ \\
\hline C24:1 & nd & $0.11 \pm 0.01$ & $0.05 \pm 0.00$ & $0.17 \pm 0.00$ & $0.07 \pm 0.01$ & $0.55 \pm 0.04$ & $0.24 \pm 0.00$ & $0.65 \pm 0.05$ \\
\hline SFA & $22.08 \pm 0.19 a$ & $17.10 \pm 0.01 \mathrm{c}$ & $18.80 \pm 0.46 b$ & $14.52 \pm 0.33 \mathrm{~d}$ & $22.51 \pm 0.54 \mathrm{a}$ & $22.63 \pm 0.24 \mathrm{a}$ & $16.36 \pm 0.86 c$ & $18.88 \pm 0.86 b$ \\
\hline MUFA & $1.52 \pm 0.06 \mathrm{~h}$ & $7.67 \pm 0.02 \mathrm{f}$ & $4.25 \pm 0.24 \mathrm{~g}$ & $40.91 \pm 1.67 b$ & $19.05 \pm 0.58 \mathrm{e}$ & $23.29 \pm 0.25 \mathrm{~d}$ & $59.85 \pm 0.51 \mathrm{a}$ & $30.16 \pm 1.39 c$ \\
\hline PUFA & $76.41 \pm 0.13 a$ & $75.23 \pm 0.02 a$ & $76.95 \pm 0.22 \mathrm{a}$ & $44.56 \pm 2.01 \mathrm{e}$ & $58.42 \pm 1.12 \mathrm{~b}$ & $54.08 \pm 0.01 \mathrm{c}$ & $23.79 \pm 1.37 \mathrm{f}$ & $50.96 \pm 0.53 \mathrm{~d}$ \\
\hline
\end{tabular}

In each row different letters mean significant differences $(p<0.05)$.

nd - not detected; C - carbon atoms; SFA - saturated fatty acids; MUFA - monounsaturated fatty acids; PUFA - polyunsaturated fatty acids.

Table 4

Tocopherol composition $(\mu \mathrm{g} / \mathrm{g})$ of the wild and commercial mushrooms (mean \pm SD; $n=3$ )

\begin{tabular}{|c|c|c|c|c|}
\hline & $\alpha$-tocopherol & $\beta$-tocopherol & $\gamma$-tocopherol & Total \\
\hline Agaricus bisporus ${ }^{\mathrm{a}}$ & $0.75 \pm 0.04 b$ & $1.66 \pm 0.01 b$ & nd & $2.41 \pm 0.05 \mathrm{cb}$ \\
\hline Agaricus silvaticus ${ }^{\mathrm{a}}$ & $0.49 \pm 0.03 c$ & $0.68 \pm 0.05 c$ & nd & $1.16 \pm 0.08$ ed \\
\hline Agaricus silvicola ${ }^{\mathrm{a}}$ & $1.30 \pm 0.01 \mathrm{a}$ & $1.93 \pm 0.01 b$ & nd & $3.23 \pm 0.00 \mathrm{~b}$ \\
\hline Boletus edulis & $0.32 \pm 0.04 d$ & $8.90 \pm 0.77 a$ & $1.42 \pm 0.07 a$ & $10.65 \pm 0.84 a$ \\
\hline Calocybe gambosa & $0.06 \pm 0.00 \mathrm{f}$ & $0.20 \pm 0.02 c$ & $0.14 \pm 0.02 c$ & $0.41 \pm 0.01$ ef \\
\hline Cantharellus cibarius & $0.12 \pm 0.00 \mathrm{f}$ & $0.03 \pm 0.01 \mathrm{c}$ & $0.03 \pm 0.00 \mathrm{~d}$ & $0.18 \pm 0.01 \mathrm{f}$ \\
\hline Craterellus cornucopioides & $0.24 \pm 0.02 \mathrm{e}$ & $1.55 \pm 0.05 b$ & $0.08 \pm 0.01 \mathrm{dc}$ & $1.87 \pm 0.02 \mathrm{~cd}$ \\
\hline Marasmius oreades & $0.06 \pm 0.00 \mathrm{f}$ & $0.19 \pm 0.09 c$ & $1.30 \pm 0.09 \mathrm{~b}$ & $1.55 \pm 0.05 \mathrm{~d}$ \\
\hline
\end{tabular}

In each column different letters mean significant differences $(p<0.05)$.

nd - not detected.

a Barros et al., 2008.

Table 5 presents phenols, flavonoids, ascorbic acid and carotenoids concentrations obtained in the extracts from the wild (Barros et al., accepted for publication) and commercial mushrooms. Phenols were the major antioxidant component detected in the extracts $(0.88-8.94 \mathrm{mg} / \mathrm{g})$, followed by flavonoids $(0.67-3.40 \mathrm{mg} / \mathrm{g})$. Ascorbic acid was found in small amounts $(0.03-0.87 \mathrm{mg} / \mathrm{g})$, and -carotene and lycopene were only found in vestigial levels $(<0.01 \mathrm{mg} / \mathrm{g})$. Wild species revealed a higher content in phenols, but a lower content in ascorbic acid than commercial mushrooms.

\subsection{Antimicrobial activity}

Table 6 shows the antimicrobial screening of mushroom extracts against B. cereus, B. subtilis, S. aureus (Gram +), E. coli, P. aeruginosa, K. peumoniae (Gram -) bacteria, and C. albicans and C. neoformans (fungi). A. silvaticus, C. cornucopioides, M. oreades and $C$. gambosa did not revealed antimicrobial properties, at the tested concentrations; the other species showed antimicrobial activity selectively against Gram + bacteria, with very low MICs. 
Table 5

Total bioactive compounds of wild and commercial mushrooms (mean \pm SD; $n=3$ )

\begin{tabular}{|c|c|c|c|c|c|}
\hline & Phenols (mg/g) & Flavonoids (mg/g) & Ascorbic acid (mg/g) & $\beta$-carotene $(\mu \mathrm{g} / \mathrm{g})$ & Lycopene $(\mu \mathrm{g} / \mathrm{g})$ \\
\hline Agaricus bisporus ${ }^{\mathrm{a}}$ & $4.49 \pm 0.16 \mathrm{~d}$ & $1.73 \pm 0.11 \mathrm{~d}$ & $0.03 \pm 0.00 \mathrm{c}$ & $1.95 \pm 0.10 \mathrm{~g}$ & $0.91 \pm 0.06 \mathrm{eb}$ \\
\hline Agaricus silvaticus ${ }^{\mathrm{a}}$ & $8.94 \pm 0.44 \mathrm{a}$ & $3.40 \pm 0.01 \mathrm{a}$ & $0.04 \pm 0.00 c$ & $5.42 \pm 0.10 \mathrm{~d}$ & $2.63 \pm 0.06 c$ \\
\hline Agaricus silvicola ${ }^{\mathrm{a}}$ & $6.18 \pm 0.44 b$ & $2.87 \pm 0.12 b$ & $0.04 \pm 0.00 c$ & $3.02 \pm 0.12 \mathrm{e}$ & $2.63 \pm 0.06 \mathrm{~d}$ \\
\hline Boletus edulis & $5.03 \pm 0.11 c$ & $1.75 \pm 0.13 \mathrm{~d}$ & nd & $2.73 \pm 0.32 \mathrm{fe}$ & $1.14 \pm 0.08 b$ \\
\hline Calocybe gambosa & $1.70 \pm 0.10 \mathrm{~g}$ & $1.18 \pm 0.16 \mathrm{e}$ & $0.40 \pm 0.01 \mathrm{~b}$ & $6.41 \pm 1.27 c$ & $3.30 \pm 0.88 b$ \\
\hline Cantharellus cibarius & $0.88 \pm 0.09 h$ & $0.67 \pm 0.11 \mathrm{f}$ & $0.86 \pm 0.01 \mathrm{a}$ & $13.56 \pm 0.51 \mathrm{a}$ & $5.06 \pm 0.33 \mathrm{a}$ \\
\hline Craterellus cornucopioides & $2.13 \pm 0.38 \mathrm{f}$ & $1.71 \pm 0.29 \mathrm{~d}$ & $0.87 \pm 0.02 a$ & $12.77 \pm 0.19 b$ & $5.13 \pm 0.14 \mathrm{a}$ \\
\hline Marasmius oreades & $3.20 \pm 0.30 \mathrm{e}$ & $2.26 \pm 0.18 c$ & nd & $1.99 \pm 0.14 \mathrm{fg}$ & $0.54 \pm 0.08 \mathrm{e}$ \\
\hline
\end{tabular}

In each column different letters mean significant differences $(p<0.05)$.

nd - not detected.

a Barros et al., accepted for publication.

Table 6

Antimicrobial activity of wild and commercial mushrooms (mean \pm SD; $n=3$ )

\begin{tabular}{|c|c|c|c|c|c|c|c|c|}
\hline \multirow[t]{2}{*}{ Samples } & \multicolumn{8}{|l|}{$\operatorname{MIC}(\mu \mathrm{g} / \mathrm{mL})$} \\
\hline & B. cereus & B. subtilis & S. aureus & P. aeruginosa & E. coli & K. peumoniae & C. albicans & C. neoformans \\
\hline Agaricus bisporus & $500(-)$ & $5(++++)$ & $500(-)$ & $500(-)$ & $500(-)$ & $500(-)$ & $500(-)$ & $500(-)$ \\
\hline Agaricus silvaticus & $500(-)$ & $500(-)$ & $500(-)$ & $500(-)$ & $500(-)$ & $500(-)$ & $500(-)$ & $500(-)$ \\
\hline Agaricus silvicola & $5(++++)$ & $50(++++)$ & $5(++++)$ & $500(-)$ & $500(-)$ & $500(-)$ & $500(-)$ & $500(-)$ \\
\hline Boletus edulis & $500(-)$ & $500(-)$ & $5(++++)$ & $500(-)$ & $500(-)$ & $500(-)$ & $500(-)$ & $500(-)$ \\
\hline Calocybe gambosa & $500(-)$ & $500(-)$ & $500(-)$ & $500(-)$ & $500(-)$ & $500(-)$ & $500(-)$ & $500(-)$ \\
\hline Cantharellus cibarius & $500(-)$ & $5(++++)$ & $50(++++)$ & $500(-)$ & $500(-)$ & $500(-)$ & $500(-)$ & $500(-)$ \\
\hline Craterellus cornucopioides & $500(-)$ & $500(-)$ & $500(-)$ & $500(-)$ & $500(-)$ & $500(-)$ & $500(-)$ & $500(-)$ \\
\hline Marasmius oreades & $500(-)$ & $500(-)$ & $500(-)$ & $500(-)$ & $500(-)$ & $500(-)$ & $500(-)$ & $500(-)$ \\
\hline Ampicillin & $3.13(++++)$ & $12.5(++++)$ & $6.25(++++)$ & $6.25(++++)$ & $6.25(++++)$ & $6.25(++++)$ & NT & NT \\
\hline Cycloheximide & NT & NT & NT & NT & NT & NT & $12.5(++)$ & $6.25(++++)$ \\
\hline
\end{tabular}

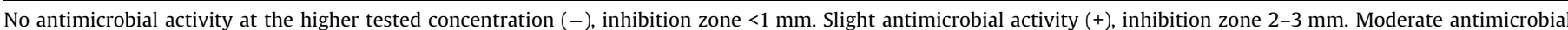

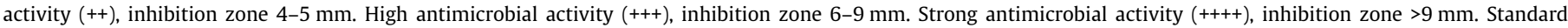
deviation $\pm 0.5 \mathrm{~mm}$. NT - not tested.

C. cibarius and $A$. bisporus revealed MIC values against $B$. subtilis even lower than the standard ampicillin. Likewise, B. edulis and $A$. silvicola revealed MIC values against $S$. aureus lower than the standard. The antimicrobial activity was not dependent of being commercial or wild mushroom, since A. bisporus and A. silvicola of the wild sp., and B. edulis and C. cibarius of the commercial sp. showed antimicrobial efficiency; it certainly depends on antimicrobials present in each mushroom species.

\section{Discussion}

Among all the studied species, only the chemical composition of A. bisporus (Manzi et al., 2001; Krbavčić and Barić, 2004), B. edulis (Manzi et al., 2004) and C. cibarius (Agahar-Murugkar and Subbulakshmi, 2005) was described previously but from different countries. Similar to our samples, the Indian $C$. cibarius contained protein as the principal macronutrient, while in the Italian B. edulis, carbohydrates dominated. The Italian $A$. bisporus sample contained higher levels of carbohydrate than proteins, while the opposite was observed in the Portuguese sample. Generally, high protein and carbohydrate contents, and low fat levels were also described by previous authors (Diéz and Alvarez, 2001). Nevertheless, the differences between the nutrient concentrations of Portuguese and Indian $C$. cibarius samples and between the Portuguese and Italian $B$. edulis and A. bisporus may be attributed to a number of factors, such as mushroom strain/type, composition of growth media, time of harvest, management techniques, handling conditions, and the preparation of the substrates (Manzi et al., 2001). The wild mushroom species proved to be less energetic than the commercial samples with a higher content of protein and a lower fat concentration.

UFA predominated over SFA in all the studied mushrooms, which is consistent with other studies (Diéz and Alvarez, 2001).
The commercial $B$. edulis contained the highest UFA contents and the lowest SFA levels, leading to an increase in HDL cholesterol and decrease in LDL cholesterol, triacylglycerol, lipid oxidation, and LDL susceptibility to oxidation (Kanu et al., 2007). The same species revealed the highest contents of tocopherols. Some authors published tocopherol determination in A. bisporus from Turkey (Elmastas et al., 2007) and B. edulis from Taiwan (Tsai et al., 2007), but using a different methodology and presenting the results per mg of extracts. In general, the commercial mushrooms revealed higher concentrations of sugars, and the wild species contained lower values of MUFA but also higher contents of PUFA. $\alpha$-Tocopherol was detected in higher amounts in the wild species, and $\gamma$-tocopherol was not found in these mushrooms. Wild samples revealed a higher content in phenols, but a lower content in ascorbic acid than commercial mushrooms.

There were no differences between the antimicrobial properties of wild and commercial mushrooms. The entire extracts were used to measure potential health benefits taking advantage of the additive and synergistic effects of all the bioactive compounds present in the extracts. Therefore, mushrooms might be used not only for their nutritional properties but also as a source for the development of drugs and nutraceuticals. Future studies should be done in order to conclude the mechanism of action involved in antimicrobial growth inhibition; there might be other compounds, besides those quantified in this study, which contribute to antimicrobial properties of the wild and commercial species. The bioactive compounds present in the extracts could be structurally related to e.g. vancomycin or bacitracin which are only effective against Gram + bacteria.

Recently, the widely consumed Tricholoma flavovirens caused delayed rhabdomyolysis in twelve humans from France and Poland, and also in mice after administration of consecutive meals 
of extracts of this mushroom (Bedry et al., 2001). The investigation was extended, first to B. edulis (Nieminen et al., 2005) and then to other species such as C. cibarius, Russula spp., Leccinum versipelle, Albatrellus ovinus, (Nieminen et al., 2006). The results indicated elevations in the plasma creatine kinase activities and additional effects on the liver transaminases and plasma creatinine in experimental mice. There has also been a concern about the safety of $A$. bisporus, an extensively consumed mushroom worldwide. Some authors demonstrated that lifetime administration of uncooked $A$. bisporus to mice induced tumours at a number of sites. However, when air-dried mushroom were fed to rats for 500 days, no carcinogenic effect was evident (Walton et al., 1998). Other authors suggested that diets high in A. bisporus may modulate the aromatase activity and function in chemoprevention in postmenopausal women by reducing the in situ production of estrogen (Grube et al., 2001). However, these findings should be interpreted carefully since these wild mushrooms have been considered safe for millennia. The harmful effects require prolonged daily exposure and high amounts of ingested mushroom (Nieminen et al., 2005).

The analyzed mushrooms contain very useful nutraceuticals such as UFA, phenolics, tocopherols, ascorbic acid, and carotenoids which could be extracted for the purpose of being used as functional ingredients namely against microbial infections. Public health authorities consider prevention and treatment with nutraceuticals a powerful instrument in maintaining and promoting health, longevity and life quality. The beneficial effects of nutraceuticals will undoubtedly have an impact on nutritional therapy; they also represent a growing segment of today's food industry. Besides, these mushrooms might be used directly in diet and promote health, taking advantage of the additive and synergistic effects of all the bioactive compounds present.

\section{Conflict of interest statement}

The authors declare that there are no conflicts of interest.

\section{Acknowledgement}

The authors are grateful to Foundation for Science and Technology (PPCDT/AGR/56661/2004) for financial support of this work.

\section{References}

Agahar-Murugkar, D., Subbulakshmi, G., 2005. Nutritional value of edible wild mushrooms collected from the Khasi hills of Meghalaya. Food Chem. 89, 599603.

Andlauer, W., Fürst, P., 2002. Nutraceuticals: a piece of history, present status and outlook. Food Res. Int. 35, 171-176.

AOAC, 1995. Official methods of analysis. 16th ed., Arlington VA, USA: Association of Official Analytical Chemists.

Barros, L., Ferreira, M.-J., Queirós, B., Ferreira, I.C.F.R., Baptista, P., 2007a. Total phenols, ascorbic acid, (-carotene and lycopene in Portuguese wild edible mushrooms and their antioxidant activities. Food Chem. 103, 413-419.

Barros, L., Calhelha, R.C., Vaz, J.A., Ferreira, I.C.F.R., Baptista, P., Estevinho, L.M. 2007b. Antimicrobial activity and bioactive compounds of Portuguese wild edible mushrooms. Eur. Food Res. Technol. 225, 151-156.

Barros, L., Baptista, P., Correia, D.M., Casal, S., Oliveira, B., Ferreira, I.C.F.R., 2007c. Fatty acid and sugar compositions, and nutritional value of five wild edible mushrooms from Northeast Portugal. Food Chem. 105, 140-145.

Barros, L., Baptista, P., Correia, D.M., Morais, J.S., Ferreira, I.C.F.R., 2007d. Effects of conservation treatment and cooking on the chemical composition and antioxidant activity of Portuguese wild edible mushrooms. J. Agri. Food Chem. 55, 4781-4788.

Barros, L., Baptista, P., Ferreira, I.C.F.R., 2007e. Effect of Lactarius piperatus fruiting body maturity stage on antioxidant activity measured by several biochemical assays. Food Chem. Toxicol. 45, 1731-1737.

Barros, L., Correia, D.M., Ferreira, I.C.F.R., Baptista, P., Buelga, C.S., 2008. Optimization of the determination of tocopherols in Agaricus sp. edible mushrooms by a normal phase liquid chromatographic method. Food Chem. $110,1046-1050$
Barros, L., Falcão, S., Baptista, P., Freire, C., Vilas-Boas, M., Ferreira, I.C.F.R., accepted for publication. Antioxidant activity of Agaricus sp. mushrooms by chemical, biochemical and electrochemical assays. Food Chem.

Bazzano, L.A., He, J., Ogden, L.G., 2001. Legume consumption and risk of coronary heart disease in US men and women: NHANES I epidemiologic follow-up study. Arch. Int. Med. 161, 2573-2578.

Bedry, R., Baudrimont, I., Deffieux, G., Creppy, E.E., Pomies, J.P., Ragnaud, J.M., Dupon, M., Neau, D., Gabinski, C., De Witte, S., Chapalain, J.C., Godeau, P., 2001. Wild-mushroom intoxication as a cause of rhabdomyolysis. New Engl. J. Med. 345, 798-802.

Çağlarirmak, N., 2007. The nutrients of exotic mushrooms (Lentinula edodes and Pleurotus species) and an estimated approach to the volatile compounds. Food Chem. 105, 1188-1194.

Courtecuisse, R., Duhem, B., 1995. In Mushrooms and Toadstools of Britain and Europe. HarperCollins Publishers, London.

Diéz, V.A., Alvarez, A., 2001. Compositional and nutritional studies on two wild edible mushrooms from northwest Spain. Food Chem. 75, 417-422.

Elmastas, M., Isildak, O., Turkekul, I., Temur, N., 2007. Determination of antioxidant activity and antioxidant compounds in wild edible mushrooms. J. Food Comp. Anal. 20, 337-345.

Fang, Y.Z., Yang, S., Wu, G., 2002. Free radicals, antioxidants, and nutrition. Nutrition $18,872-879$.

Fürst, P., Kuhn, K.S., 2000. Fish oil emulsions: what benefits can they bring? Clin. Nutrition 19, 7-14.

Grube, B.J., Eng, E.T., Kao, Y.-C., Kwon, A., Chen, S., 2001. White button mushroom phytochemicals inhibit aromatase activity and breast cancer cell proliferation. J. Nutr. 131, 3288-3293.

Harada, A., Gisusi, S., Yoneyama, S., Aoyama, M., 2004. Effects of strain and cultivation medium on the chemical composition of the taste components in fruit-body of Hypsizygus marmoreus. Food Chem. 84, 265-270.

Hatvani, N., 2001. Antibacterial effect of the culture fluid of Lentinus edodes mycelium grown in submerged liquid culture. Int. J. Antimicrob. Agents 17, 7174.

Hirasawa, M., Shouji, N., Neta, T., Fukushima, K., Takada, K., 1999. Three kinds of antibacterial substances from Lentinus edodes (Berk.) Sing. (Shiitake, an edible mushroom). Int. J. Antimicrob. Agents 11, 151-157.

Kanu, P.J., Zhu, K., Kanu, J.B., Zhou, H., Qian, H., Zhu, K., 2007. Biologically active components and nutraceuticals in sesame and related products: a review and prospect. Trends Food Sci. Technol. 18, 599-608.

Krbavčić, I.P., Barić, I.C., 2004. Influence of deep fat frying on some nutritional parameters of novel food based on mushrooms and fresh soft cheese. Food Chem. 84, 417-419.

Kruger, C.L., Mann, S.W., 2003. Safety evaluation of functional ingredients. Food Chem. Toxicol. 41, 793-805.

Lindequist, U., Niedermeyer, T.H.J., Julich, W.-D., 2005. The pharmacological potential of mushrooms. eCAM 2, 285-299.

Liu, R.H., 2003. Health benefits of fruits and vegetables are from additive and synergistic combination of phytochemicals. Am. J. Clin. Nutr. 78, 517S-520S.

Lo, K.M., Cheung, P.C.K., 2005. Antioxidant activity of extracts from the fruiting bodies of Agrocybe aegerita var. alba.. Food Chem. 89, 533-539.

Manzi, P., Aguzzi, A., Pizzoferrato, L., 2001. Nutritional value of mushrooms widely consumed in Italy. Food Chem. 73, 321-325.

Manzi, P., Marconi, S., Aguzzi, A., Pizzoferrato, L., 2004. Commercial mushrooms: nutritional quality and effect of cooking. Food Chem. 84, 201-206.

Mau, J.-L., Lin, H.-C., Chen, C.-C., 2002. Antioxidant properties of several medicinal mushrooms. J. Agri. Food Chem. 50, 6072-6077.

Moser, M., 1983. In Keys to Agarics and Boleti (Polyporales, Boletales, Agaricales, Russulales). Roger Phillips, London.

Nieminen, P., Mustonen, A.-M., Kirsi, M., 2005. Increased plasma creatine kinase activities triggered by edible wild mushrooms. Food Chem. Toxicol. 43, 133138.

Nieminen, P., Kirsi, M., Mustonen, A.-M., 2006. Suspected myotoxicity of edible wild mushrooms. Exp. Biol. Med. 231, 221-228.

Ribeiro, B., Valentão, P., Baptista, P., Seabra, R.M., Andrade, P.B., 2007. Phenolic compounds, organic acids profiles and antioxidative properties of beefsteak fungus (Fistulina hepatica). Food Chem. Toxicol. 45, 1805-1813.

Smânia Jr., A., Monache, F.D., Smânia, E.F., Gil, M.L., Benchetrit, L.C., Cruz, F.S., 1995. Antibacterial activity of a substance produced by the fungus Pycnoporus sanguineus (Fr.) Murrill. J. Ethnopharmacol. 45, 177-181.

Soobrattee, M.A., Neergheen, V.S., Luximon-Ramma, A., Aruoma, O.I., Bahorun, T., 2005. Phenolics as potential antioxidant therapeutic agents: mechanism and actions. Mutation Res. 579, 200-213.

Tsai, S.-Y., Tsai, H.-L., Mau, J.-L., 2007. Antioxidant properties of Agaricus blazei, Agrocybe cylindracea, and Boletus edulis. LWT 40, 1392-1402.

Turkoglu, A., Duru, M.E., Mercan, N., Kivrak, I., Gezer, K., 2007. Antioxidant and antimicrobial activities of Laetiporus sulphureus (Bull) Murrill. Food Chem. 101, 267-273.

Walton, K., Walker, R., Ioannides, C., 1998. Effect of baking and freeze-drying on the direct and indirect mutagenicity of extracts from the edible mushroom Agaricus bisporus. Food Chem. Toxicol. 36, 315-320.

Wasser, S.P., Weis, A.L., 1999. Medicinal properties of substances occurring in higher basidiomycetes mushrooms: current perspectives (review). Int. J. Med. Mushrooms 1, 31-62. 